\title{
1. Hiring, Firing, Roles and Responsibilities
}

\author{
Keith Dowding and Chris Lewis
}

\begin{abstract}
Accountability for government action and inaction has always been central to the study of government in political science and public administration. In Westminster systems such as Australia's, the heart of academic and media discussion lies in the issue of ministerial accountability. Traditionally the idea behind the Westminster system is that whilst civil servants advise and administer policy, their public face is their minister, who promotes policy and defends department action in parliament and in public. Naturally this directs public attention to ministers and to the processes by which ministers and, through them, public servants are held to account. The manner in which ministers are chosen, how they see their jobs and how they do their jobs are thus key aspects of the governmental and accountability processes.
\end{abstract}

This book examines the roles, responsibilities and accountabilities of Australian Commonwealth cabinet ministers. We will examine what sorts of jobs ministers do, what is expected of them and what they expect of the job. We will examine how they (are supposed to) work together as a team. We will consider aspects of how they are chosen to become ministers, how they are scrutinised by parliament and to some extent by the media, and how ministers view the accountability mechanisms themselves. Subsequent chapters will then explore what the public often considers to be the heart of ministerial accountability: the issues that lead to calls for them to resign. We examine in some detail scandals around ministers. Our final chapter assesses ministerial accountability.

This first chapter will examine the roles that ministers are asked to perform and establishes some background theory. We consider the traditional constitutional account of responsibility as well as positive theories about how we can expect accountability mechanisms to work in practice. We explore issues that prime ministers might take into account when choosing ministers and when releasing them from their duties. The chapter performs most of these tasks by reflecting upon and introducing the more detailed accounts to be found in the chapters that follow. 


\section{The Role and Responsibilities of Ministers}

The Governor-General officially appoints Australian ministers under Section 64 of the Constitution. In practice, within the Labor Party, until Kevin Rudd, the party caucus chose ministers though not necessarily their portfolios. Within the Coalition, Liberal prime ministers need to take account of the Country or National Party partners. Powerful ministers with strong party backing, notably those who lose leadership contests, become deputy prime minister and choose their own portfolio, often finance. These complications aside, we can think of ministers as agents of the prime minister. A cabinet forms a single government and it is in each member's interest to work together as a team-as John Wanna describes in Chapter 2-despite conflicts of interest and rivalries.

Until 1987 when legal advice changed, all ministers had to be appointed to their own department; now they can be appointed 'to administer' a department. Ministers often take on more than one portfolio or area of responsibility. They have 'individual ministerial responsibility' not only for their own personal conduct but also for their portfolios. Traditionally this involves administering their department and taking ultimate responsibility for what goes on in their area of responsibility. This includes reporting on the activities of their department to parliament and the public, either directly, through public statements or the prime minister answering on their behalf; explaining why problems emerge in implementation or execution and taking action to make improvements through new administrative procedures, oversight of or direct action by public officials; or through introducing new legislation.

Parliamentary democracy thus operates through a 'chain of delegation' (Strøm 2003) that links the electorate to the executive. The link runs from voters as principals to Members of Parliament (MPs) as agents. MPs are organised as collections of parties and from these the government is formed. The backbenchers and party then form the principals with the executive as the agent. The parliament delegates to the government the role of initiating policies. The prime minister is thus an agent of her party in parliament, and she in turn acts as a principal to the minsters who form her cabinet. Finally cabinet ministers act as principals and their public servants act as their agents. Each link in the chain is an important part of accountability within parliamentary democracies.

These are the important aspects of individual ministerial responsibility. The public face of such individual responsibility is generally witnessed when the minister is 'sacrificed' (read resigns) over some scandal or issue within his remit. In some sense 'sacrificial responsibility' is a minor part of individual ministerial responsibility, but it is a key element in accountability; if ministers never felt threatened then they would feel less pressure to demonstrate competence in 
administering, reporting, explaining and improving within their remit. Chapter 6 examines the operation of sacrificial responsibility in recent years in Australia, but we should acknowledge that what there is described as 'forced exit' is only one stark aspect of a minister's career prospects that makes him accountable. Ministers might not resign at the time they are criticised but, in the United Kingdom at least, it has been shown that ministerial durability is affected by the number of times they are criticised and the number of times their colleagues are criticised (Berlinski et al. 2010, 2012). The prime minister and her party want ministers who perform well; those who perform badly will leave the cabinet and often parliament at the same time or shortly thereafter. Any minister who is seen as an electoral liability will be less durable than those who perform well. Of course, if a government does badly as a whole then all the ministers will pay the price.

Individual ministerial responsibility is thus inextricably linked to collective responsibility. Any minister who is deemed to be in trouble can expect the support of his colleagues. First, any organised collective that sees one of its members under fire is likely to want to defend that member since damage to one will damage them all. There is a collective interest in defending ministers. Second, ministers will have an individual interest in seeing their colleagues defended by their prime minister and party since they might be under fire themselves in the future; however, such defence will only continue whilst the damage can be limited. If a minister is severely damaging the government's re-election prospects then support will be withdrawn. Having said that, governments can weather much criticism of individual ministers; what matters is the relative popularity of the government. The key minister with regard to the government's re-election prospects is the prime minister herself.

Collective ministerial responsibility requires that ministers support each other and the government. In its traditional garb it requires that whilst ministers might debate furiously behind the scenes or in cabinet over some political issue, once the government line has been laid down they will all publicly support it. Again important for re-election prospects, this ensures that the government team at least looks unified. It supports individual responsibility to the extent that each minister is responsible for their own area of responsibility, so ministers should support each other's policies as developed within their own remit. In practice most policies encroach upon several areas of responsibility and much of the work of public servants, these days, in the early stages of policy formation involves liaising across ministers and departments to ensure agreement. Such liaison, whether through official cabinet committees or informally, has always been the real heart of cabinet government. Nevertheless, in Australia, more so than in the United Kingdom, the formal cabinet meeting remains an important decision-making forum. 
Ministers do come into conflict over policy and vie with each other for preeminence or dominance. Parliamentary sitting times are short and there is limited time to introduce legislation; ambitious ministers will want their bills as high on the agenda as possible. Some ministers will be seen as more important and awarded portfolios where the prime minister wants action. In Australia ministers have scope for putting themselves forward, through major speeches, appearances on television, in newspaper articles or new media. Whilst prime ministers take collective responsibility seriously, sometimes they have had to ignore or selectively interpret statements by ministers, effectively skirting the boundaries of collective responsibility (Weller 1985). Ministers can also allow the public to glimpse conflict through leaks and through friendly journalists reporting and speculating. Prime ministers despair of such selective leakingand are the most assiduous practitioners of it. John Wanna in Chapter 2 carefully examines what collective responsibility has been interpreted to mean in Australia.

Many commentators argue that prime ministers have become more powerful, not only in Australia but also in all the Westminster countries and indeed other parliamentary democracies (Pogunkte and Webb 2005). In part this is presentational. With increasing media attention focusing on people, there has been, worldwide, a personalisation of politics (McAllister 2007). How far this media presentation reflects the actual running of government, however, is another issue. Robert Menzies, partly due to his long tenure, which lent him authority and caused his ministers to owe him their position, was certainly a dominant figure - more so than his immediate predecessors. Malcolm Fraser and Rudd both required detailed information about all areas of government, whereas Bob Hawke was seen as the supreme chairman of cabinet, allowing ministers their own initiative but intervening where necessary (Weller 2007). Gough Whitlam wanted to run everything - an approach that can become disastrous if the prime minister cannot control his cabinet (as was the case with William McMahon). John Howard and Rudd were decisive, setting the agenda and making decisions - in Rudd's case, often without even consulting the relevant minister. Rudd's domination of his cabinet in this manner was not unimportant in his rapid demise (see Chapter 2), which tells us as much about cabinet government as the fact that he had the resources to dominate in such a manner. If we want to study the growing centralisation of policy making and the ability of prime ministers to control their cabinets-sometimes dubbed 'prime ministerialisation' (Dowding 2012) — we need to look at the growth of their resources. ${ }^{1}$ The Prime Minister's Office (PMO) and the Department of the Prime Minister and Cabinet (PM\&C), which provide the central coordinating machinery and planning for the prime minister, have grown in personnel and

1 The 'prime ministerialisation' designation was chosen to counter the institutionally and behaviourally naive 'presidentialisation of prime minister' thesis. 
resources; however, governments have always struggled and will continue to struggle to keep abreast of the complexities and interrelationship of policies across the spectrum of government.

The role and responsibilities of ministers have changed over time, as Anne Tiernan and Patrick Weller discuss in their book (Tiernan and Weller 2010). Nevertheless, there are a number of general functions performed by ministers that have altered relatively little. Ministers are responsible within the remit of their job in several senses, to announce, explain and to defend the policies and actions of their department but also to initiate some of the policies and actions. An important aspect of their role is to represent their departments in interdepartmental forums and when negotiating policy, and to fight for time to get their legislative agenda through parliament. To be sure, public servants and policy advisers do the bulk of such work, but at times, as advised by these staff, ministers do get involved. Departments compete with each other over scarce resources and ministers help their public servants in negotiations with finance, meeting with clients and pressure groups. Again, public servants conduct the bulk of such work, but ministers need to be prepared to take on the responsibility of making as well as signing off on decisions and agreements when required. Ministers will engage in cabinet and cabinet committees, and defend their department and represent its views, in discussion of the policies and plans of other ministers. Of course as elected Members of Parliament they retain their parliamentary roles of representing constituents and their factions within the party.

One of the problems of the ministerial role is that the choice mechanism does not necessarily reflect the job that a minister has to do. To become a minister a person has to convince first the party and then the broader electorate of their qualities. He then has to convince the party hierarchy. This can be achieved partly through the organisational qualities displayed in his party work or previous occupations; but crucially he must be able to demonstrate that he can handle the rough and tumble of politics. Ministers' public exposure has increased with the onset of the 24-hour media cycle and social media; ministerial offices are now expected to respond almost instantly to emails or Twitter gossip.

\section{Cabinet Composition and Teamwork}

Most of the items on the list of ministerial functions relate to their roles as individual ministers, and in that sense they concern individual ministerial responsibility. Within that framework the public image and the public manner of the minister are important, as is their role as part of the government. John Wanna in Chapter 2 considers the role of ministers as part of a cabinet team. As 
we have suggested, cabinets are composed of ambitious sets of politicians who are rivals as well as colleagues. The strong party nature of Australian politics ensures that ministers share some sets of policy preferences and ideological concerns, but within broad lines their views can differ sharply. Cabinets are composed of powerful figures who represent factions where conflicts can run deep and have long histories. Cabinet members are likely to have known each other for many years and to be strong personalities who have previously clashed over policy or even stood against each other for party positions or for seats at local, State or even national levels. ${ }^{2}$ Despite all that, they must pull together and be part of a government team. The convergent and divergent sets of interests create a collective-action problem, with incentives, at times, pulling in different directions. Ministers are agents of their party and of the prime minister, and if any one of them is seen as too divisive, and so damaging the government and ultimately the party's chances of re-election, he will be punished by their backbenchers. Ministers must therefore provide a semblance of coherence and consistency. More than that, however, they must work together as a team.

The prime minister is the key player in forging the cabinet as a team, but other powerful ministers also play key roles; and we have seen over the years rivalries that have damaged the team: Hawke and Paul Keating, Howard and Peter Costello - both to some extent because of supposed deals over the leadership formerly agreed. The main thrust of Wanna's chapter, however, is a consideration of what collective responsibility really means in practice. His discussion helps mitigate the imbalance of so much concentration upon individual ministerial responsibility. His major conclusion is that collective responsibility is as much about the appearance of a unified government and the interpretations of working together that a prime minister is prepared, or sometimes forced, to accept, given the personalities and conflicts amongst his team. Importantly, the idea (the 'myth' perhaps) of collective responsibility is something that has to be accepted by all, under a broad interpretation, in order for government to work. Furthermore, what some prime ministers (Rudd might be an example) sometimes seem to forget is that collective responsibility holds for them too. As Wanna suggests, cabinet is a bridge between the prime minister and the party; but it also acts as the party's leash upon the prime minister - a leash that is slackened depending on how successful the government appears to be.

2 A story told of Winston Churchill is as relevant to Australia as it is to the United Kingdom. A newly elected MP leaned forward and whispered to Churchill how good it was to face the enemy across the House of Commons. 'The enemy is beside and behind us', replied Churchill, 'facing us is merely the Opposition.' 


\section{Choosing Ministers}

John Wanna describes elements of that team and how a government must have some overarching principles that govern the whole. Furthermore, teamwork in a complex organisation like government is not simply pulling together like a tug-of-war side but rather entails different members doing different jobs. A good governing team will have within it elder statesmen, Rottweilers to maul the opposition, those with dynamic ideas and those considered safe pairs of hands. The prime minister will also want a set of loyal lieutenants. Biographies show that prime ministers usually have a strong idea of who they want in most positions, and probably agonise more over the final few places than over the bulk of them. In Australia it is important that the cabinet is representative of the different States roughly in proportion to the size of their population, and leaders these days want some degree of gender balance. Nevertheless, there might be specific qualities leading some parliamentarians to ministerial posts that even prime ministers themselves do not fully recognise. These are the qualities that Michael Dalvean attempts to uncover in Chapter 3.

Dalvean uses words as data to try to examine the psychological characteristics that lead some to become ministers. He tries to predict who will be chosen as a minister, and who will be successful once there, based upon the maiden speeches of parliamentarians. Given those data, he adds other factors, such as the member's State, gender, educational background, and so on, to predict who will be ministers. In fact, he argues that representativeness does not add anything to his predictive model. His argument here is subtle and open to misunderstanding. He does not claim that prime ministers do not explicitly take into account representativeness when considering candidates for ministerial position; indeed we know from biographical accounts that such discussions about representativeness do take place during the composition of the cabinet. He argues, however, that representativeness does not really explain the actual composition. How can that be?

One way of thinking about the issue is to imagine the choice of, say, 20 stones from six urns. There are 150 stones overall distributed among the urns in the proportions $10,10,20,20,45,45$. Now say we want to choose the 20 smoothest stones, and the stones have been randomly assigned to each urn. If we were to randomly pick a stone from the 150 we would have a one in 7.5 chance of picking one of the 20 smoothest. The chance of one of the smoothest being in any given urn is thus $(1 / 7.5)^{*} n$ where $n$ is the number of stones in the urn. Now consider a non-random choice. Imagine we get to feel each of the stones in turn and choose the 20 smoothest. How many are likely to be picked from each urn? 
The answer of course is $(1 / 7.5)^{*} n$. So we would expect to pick one-two stones from the first two urns (prob. = 1.3), two-three from the second two (prob. $=$ 2.6) and five--six (prob. = 5.3) from the two largest urns.

Now consider that each urn has stones of a different colour in it and we want to choose stones representative of the urns. So now we want to choose 20 stones out of the 150 in proportion to how many of the stones are in each urn. Our calculation is $(20 / 150)^{*} n$ from each urn. Of course, this is the same calculation, so we would expect one-two stones from the smallest urn, two-three from the middle and five-six from each of the largest. Either way of choosing cannot distinguish the stones by the numbers chosen. We can of course understand which way of choosing occurs by inspecting the colours or the smoothness. If only colour matters then we might assume that representativeness has been the key element. If smoothness is what matters then we can assume stones have been chosen by shape. Michael Dalvean argues that the most predictive way of seeing who becomes a cabinet minister is from their personal characteristics as identified by their maiden speech in parliament and not from their State. It is smoothness $=$ psychological characteristics, not urn $=$ State, that gives the predictions of the actual stones $=$ members chosen. Dalvean does not need to deny that representativeness seems to matter but it seems to matter only because the personal characteristics that cause someone to be seen as a viable minister are normally distributed across the States. It might be true that a prime minister plumps for candidate B over candidate A simply because he is from one of the States that otherwise might be under-represented, but that is only because the number of qualified candidates (given some stochastic variance) does not equal the precise number of ministers required. In other words, even if Australia were not a federal system with State boundaries and some constitutional niceties of representativeness, much the same cabinets would be chosen anyway. If we could operate the counterfactual - what if the qualities that make ministers were not normally distributed across representatives of the States? - then we might see whether State representation matters more than candidate quality.

So Dalvean looks to personal psychological factors. Examining the maiden speeches of Members of Parliament through computer-assisted word search, he statistically collates sets of words and phrases that are strongly correlated with future office, distinguishing those MPs who become ministers from those who do not. He predicts who can become a minister through analysis of MPs' maiden speeches. He then psychologically analyses those words and phrases to see if he can demonstrate what characteristics are associated with becoming a minister (as opposed to not becoming one) and what is associated with longer ministerial careers (as a proxy for being a successful minister). He finds that ministers have qualities that distinguish them from MPs. He also finds that there are differences between Labor and Coalition governments. 
We have seen that prime ministers might not always get the cabinet team they fully desire. Even when the prime minister does control the process, he or she will be forced to find jobs for the big beasts, and those beasts might demand specific roles. They have to keep different factions happy and sometimes find a role for someone whose time has passed perhaps, but who is still important politically. Dewan and Hortala-Vallve (2011) discuss the three As of government formation: appointment, allocation and assignment. Often we concentrate upon the appointment aspect, but prime ministers can hide ministers in unimportant portfolios, assign them to unpopular ones and to some extent reassign the nature of the responsibilities within a portfolio. Peter Costello $(2008,55)$ describes the last (albeit in opposition):

When we got back to Canberra after John Hewson appointed me shadow attorney-general, Hewson called me down to his office. He explained that he had previously appointed [Andrew] Peacock to the job because he needed to give him a portfolio as senior as that held by John Howard. He told me: 'It was a clever strategy. No one caught on that in fact I had gutted the portfolio and given the substantive responsibilities to you.'

Prime ministers have some discretion as to what specific responsibilities are assigned to each portfolio; they can move the chairs around within departments as well as assigning the chairs to departments. They control more than the actual appointments.

\section{Ministerial Accountability}

Where Dalvean uses quantitative techniques, James Walter in Chapter 4 uses the qualitative technique of in-depth interviews to examine the attitudes of ministers to their job and to the issue of executive accountability. He draws upon two sets of interviews: one conducted when the interviewees first entered parliament about 30 years ago, and the second more contemporary. He compares the attitudes of his interviewees towards executive accountability when they first entered parliament and again after they had held office; and compares the attitudes of those who held office with those who did not. In doing so he explores whether the experience of ministerial office leads to a change in attitudes to executive accountability, especially in relation to party and parliamentary oversight. Interestingly, he finds that even prior to high office some different attitudes emerge. The more ambitious backbenchers tend to rate the processes by which the executive makes decisions, and the decisions themselves, more highly than the less ambitious. The latter recognise the realities that the legislature is not very influential in executive decisions but believe it ought to have a bigger role. Backbenchers also rate their role of representing their 
constituency more highly. Walter categorises the parliamentarians according to the sorts of answers they give. Some are policy activists who see their careers in terms of how they influence policy - they tend to be more ambitious for an executive role. Parliamentarians see their role in parliament and the caucus of their party as important; delegates put their constituency representation at the forefront. Those who later made it to the executive recognise the accountability function of parliament but also see its limitations. They also tended to see the party caucus as less important to the executive than they did as backbenchers. This might reflect the fact that whilst caucus might seem to direct, often since the cabinet is chosen by caucus (or chosen by the prime minister who is chosen by caucus), the views of the executive and caucus are not so far apart. On those few occasions when views diverge, the executive prevails most often.

Walter chronicles change. He chronicles the greater ambition of later generations, how the age profile is getting younger and the growing professionalisation of politics - the last marked by the greater numbers who have always worked in politics as opposed to those who had more life experience prior to their political careers. Importantly, as his title suggests, he finds a democratic ambivalence towards attitudes to accountability. The greater ambiguity lies in those who are more ambitious.

Phil Larkin looks carefully at the formal processes of parliamentary scrutiny, carried out both through the chamber and the committee system. He examines the contested decline of parliament as a mechanism of accountability. First, we ought to acknowledge the counterfactual. We might lament that ministers do not fear parliament as much as they might, or believe that parliament ought to have more powers, or perhaps just use the powers they have more often and more effectively. But we should begin by considering what the executive might do if there were no parliament. That is, we must first recognise the vast difference between the behaviour of the executive in parliamentary democracies and dictatorships and their puppet legislatures.

Parliament can ensure that ministers explain their decisions and account for their policies and the public service. That in itself is an important function. Larkin also brings out the fact that parliament is not a single actor, and there is a series of relations - between ministers and their own backbenchers, and between ministers and the opposition parties. He argues that Question Time is not a very effective process; rather we need to look to the committee structure for more effective means of accountability. His careful study brings out the strength and the weakness of the committees in both houses, but also acknowledges that trying to understand or quantify their effectiveness is exceedingly problematic. He highlights the importance in this respect of the bicameral system. The Senate by repute is a more deliberative assembly that stands a little aside from the day-to-day affray of government versus opposition. Given that it is elected by 
a different system, ensuring that neither Labor nor the Coalition will normally have majorities there, can the Senate perform a more reflective role? Or do we find that the rough and tumble of adversarial politics override any institutional differences? Larkin also considers the important change we have seen in the past two or three decades: the rise of the ministerial adviser and the fact that parliamentary rules and accountability conventions have not fully adjusted to this innovation.

Keith Dowding, Chris Lewis and Adam Packer take a longer look at accountability, especially that aspect of accountability that has been dubbed 'sacrificial accountability' (Woodhouse 1994). To be sure, such accountability is only part of the nature of ministerial responsibility. In the popular mind, however, ministerial accountability involves resigning for personal mistakes. Academics have long argued that government accountability is much broader than this (Dowding 1995, Ch. 7; Dowding and Kang 1998; Mulgan 2000; Robinson et al. 1987; Weller 1999; Woodhouse 1994, 2002, 2003), while also recognising that resignation needs to underpin accountability for grave errors (Page 1990; Thompson and Tillotsen 1999). Both John Howard and Kevin Rudd made it clear that they saw it as an important aspect of responsibility, at least at the beginning of their office, by bringing in codes of conduct (Howard 1996; Rudd 2007). Dowding et al. use a unique data set that examines all forced exits from the cabinet since 1947 to make judgments about whether ministers are more or less accountable now than in the past. These questions have taken on a more vibrant tone in the past 20 years, largely because it was thought that John Howard's ministers seemed teflon coated - continuing in office despite many scandals. Dowding et al. demonstrate that in fact the rate at which Howard lost ministers relative to calls for resignation was not so different from the past; what differed was that he lost so many in his first two years and then seemed determined to keep them.

Dowding et al. argue that the rate at which ministers forcibly exit relative to calls has gone down, but that this is due to the greater number of calls that are made. They argue that issues that once were not considered worthy of public examination now are. In that sense public scrutiny and ministerial accountability have increased not decreased, but consequently public confidence and trust in government have gone down. Scott Brenton continues this theme, examining in more detail scandals involving ministers in the past 50 years to judge whether ministerial behaviour has deteriorated over time. Chris Lewis takes a detailed look at a recent executive problem - the debacle of the Home Insulation Program - and argues that it is one of the worst failures of the executive in recent years. Caused by haste and ignoring the proper internal checks, it demonstrates a lack of accountability. 
We can, though, place too much weight on sacrificial accountability. Even if ministers do not resign at the time there are calls for them to do so, their careers may still be affected. Just because a minister does not forcibly exitis 'sacrificed' - it does not mean he or she has not been held accountable for their actions. Ministerial careers might still end: the minister might move to the backbenches after the next election or not stand at all. Howard might have defended his ministers during times when they were criticised, but he was not averse to moving them out or demoting them after the Christmas break. Australian governments - possibly because of the short terms (a three-year maximum as opposed to the United Kingdom's five years) - do not have the UK tradition of the 'mid-term reshuffle', but prime ministers do choose to shift ministers around and move some on occasionally. And not standing for another term is more common in Australia, partly again because of the short terms but largely because of the relatively small size of parliament and the preselection process where most constituency parties would sooner have members who are going somewhere than those who have been somewhere. In other words, ministerial durability is more important than the rate of forced exits in making judgments about the nature of ministerial responsibility.

The final chapter in the book, by Richard Mulgan, takes a careful look at ministerial accountability. He suggests that over-reliance on the concept of ministerial as opposed to governmental responsibility is the major problem with Westminster systems such as Australia's. Public servants no longer enjoy anonymity, making televised appearances before parliamentary scrutiny committees; the old distinctions between administration and policy no longer (if they ever did) hold; and the increasing complexity of government makes individual ministerial responsibility something of a misnomer. Furthermore, Mulgan suggests that accountability agencies like the audit office and ombudsman are important and more attention should be devoted to their role when considering governmental responsibility. He argues that the focus we often direct to individual ministers, which his extended analysis of the Home Insulation Program illustrates, deflects attention away from others who share responsibility. We should pay less attention, Mulgan advises, to individual ministerial responsibility and more to the collective aspects of ministerial responsibility; and we should pay more attention to the government machine as a whole and less to individual ministers.

\section{Conclusions}

In parliamentary systems of government, and in Westminster-style democracies especially, the role of ministers is a key element in the democratic and accountability processes. They form the public face of the political and administrative processes. Their role both as individuals and as a collective is a 
vital aspect of how we can hold executive processes together. In this book, we examine how ministers come to gain office in Australia, how well they represent different parts of the community, how they operate as a team, their behaviour in office and how they are held to account through parliamentary and public processes. Aspects of ministerial accountability are not the be-all and end-all of accountability structures in democratic systems: audit systems, ombudsmen and the judiciary all form part of the constitutional fabric of accountability. The media and the public themselves are also vital aspects of accountability.

In the end, how far ministers and governments sustain themselves relies upon their standing in the public eye, and it is this knowledge that, together with their own normative and moral principles, leads politicians to act as responsibly as they do. Richard Mulgan's concluding chapter brings us to realise that perhaps at times we place too much emphasis on individual ministerial responsibilityfailures in government often result from collective failures in organisation - and perhaps we might move too quickly to blame a public face both for our own convenience and for that of the executive. Nevertheless, ministers will always remain a vital part of the accountability process in parliamentary democracies.

\section{Bibliography}

Berlinski, S., T. Dewan and K. Dowding. 2010. 'The Impact of Individual and Collective Performance on Ministerial Tenure'. Journal of Politics 72: 1-13.

Berlinski, S., T. Dewan and K. Dowding. 2012. Accounting for Ministers: Scandal and Survival in British Government 1945-2007. Cambridge: Cambridge University Press.

Costello, P. 2008. The Costello Memoirs. Melbourne: Melbourne University Press.

Dewan, T. and R. Hortala-Vallve. 2011. 'The Three A's of Government Formation: Appointment, Allocation, and Assignment'. American Journal of Political Science 55: 610-27.

Dowding, K. 1995. The Civil Service. London: Routledge.

Dowding, K. and W.-T. Kang. 1998. 'Ministerial Resignations 1945-97'. Public Administration 76: 411-29.

Dowding, Keith 2012 'The Prime Ministerialization of the British Prime Minister' Parliamentary Affairs, Advance Access 6 April 2012 — DOI: 10.1093/pa/gss007

Howard, J. 1996. Guidelines on Ministerial Conduct. Canberra: Australian Government Publishing Service. 
McAllister, I. 2007. 'The Personalization of Politics'. In The Oxford Handbook of Political Behavior, eds R. Dalton and H.-D. Klingemann, pp. 571-88. Oxford: Oxford University Press.

Mulgan, R. 2000. 'Accountability: An Ever Expanding Concept'. Public Administration 58: 555-74.

Page, B. 1990. 'Ministerial Resignation and Individual Ministerial Responsibility in Australia 1976-1989'. Journal of Commonwealth and Comparative Politics 28: $141-61$.

Poguntke, T. and P. Webb. 2005. The Presidentialization of Politics: A Comparative Study of Modern Democracies. Oxford: Oxford University Press.

Robinson, A., F. F. Ridley and G. W. Jones. 1987. 'Symposium on Ministerial Responsibility'. Public Administration 65: 61-91.

Rudd, K. 2007. Standards of Ministerial Ethics. Canberra: Australian Government.

Strøm, K. 2000. 'Delegation and Accountability in Parliamentary Democracies'. European Journal of Political Research 37: 261-89.

Strøm, K. 2003. 'Parliamentary Democracy and Delegation'. In Delegation and Accountability in Parliamentary Democracies, eds K. Strøm, W. C. Muller and T. Bergman. Oxford: Oxford University Press.

Thompson, E. and G. Tillotsen. 1999. 'Caught in the Act: The Smoking Gun View of Ministerial Responsibility'. Australian Journal of Public Administration 58: $48-57$.

Tiernan, A. and P. Weller. 2010. Learning to Be A Minister: Heroic Expectations, Practical Realities. Melbourne: Melbourne University Press.

Weller, P. 1985. 'The Hawke Cabinet: Collective or Responsible?'. Australian Quarterly 57: 319-32.

Weller, P. 1999. 'Disentangling Concepts of Ministerial Responsibility'. Australian Journal of Public Administration 58: 62-4.

Weller, P. 2007. Cabinet Government in Australia, 1901-2006. Sydney: UNSW Press.

Woodhouse, D. 1994. Ministers and Parliament: Accountability in Theory and Practice. Oxford: Oxford University Press.

Woodhouse, D. 2002. 'The Reconstruction of Constitutional Accountability'. Public Law: 73-90.

Woodhouse, D. 2003. 'Ministerial Responsibility in the Twentieth Century'. In The Constitution in the Twentieth Century, ed. V. Bogdanor, pp. 281-332. Oxford: Oxford University Press. 